10. Andrade J, Batista M, Evora P, Tavares JR, Buffolo E, Ribeire EE, et al. Methylene blue administration in the treatment of the vasoplegic syndrome after cardiac surgery. Rev Bras Circ Cardiovasc. 1996;11:207-14.

11. Leyh RG, Kofidis T, Struber M, Fischer S, Knobloch K, Wachsmann B, et al. Methylene blue: the drug of choice for catecholamine-refractory vasoplegia after cardiopulmonary bypass? J Thorac Cardiovasc Surg. 2003;125:1426-31.

12. Levin RL, Degrange MA, Bruno GF, Del Mazo CD, Taborda DJ, Griotti JJ, et al. Methylene blue reduces mortality and morbidity in vasoplegic patients after cardiac surgery. Ann Thorac Surg. 2004;77:496-9.

13. Stanford SC, Stanford BJ, Gillman PK. Risk of severe serotonin toxicity following co-administration of methylene blue and serotonin reuptake inhibitors: an update on a case report of post-operative delirium. J Psychopharmacol. 2010;24:1433-8.

14. Gillman PK. CNS toxicity involving methylene blue: the exemplar for understanding and predicting drug interactions that precipitate serotonin toxicity. J Psychopharmacol. 2011;25:429-36.

15. Sternbach H. The serotonin syndrome. Am J Psychiatry. 1991;148:705-13.
16. Dunkley EJ, Isbister GK, Sibbritt D, Dawson AH, Whyte IM. The Hunter serotonin toxicity criteria: simple and accurate diagnostic decision rules for serotonin toxicity. Q J Med. 2003;96:635-42.

17. Boyer EW, Shannon M. The serotonin syndrome. N Engl J Med. 2005;352: 1112-20.

18. Food and Drug Administration. FDA drug safety communication: serious CNS reactions possible when methylene blue is given to patients takeing certain psychiatric medications. 2011. Available from: http://www.fda.gov/Drugs/DrugSafety/ ucm263190.htm. Accessed January 14, 2012.

19. Food and Drug Administration. FDA drug safety communication: updated information about the drug interaction between methylene blue (methylthioninium chloride) and serotonergic psychiatric medication. 2011. Available from: http:// www.fda.gov/Drugs/DrugSafety/ucm276119.htm. Accessed January 14, 2012.

20. Shapiro PA, Levin HR, Oz MC. Left ventricular assist devices: psychosocial burden and implications for heart transplant programs. Gen Hosp Psychiatry. 1996; 18:30S-5S.

\title{
The reliability of lung function tests in a quadriplegic patient
}

\author{
Pierre Emmanuel Noly, MD, Alex Arame, MD, Marc Riquet, $\mathrm{PhD}$, MD, and \\ Françoise Le Pimpec-Barthes, PhD, MD, Paris, France
}

There are few quadriplegic patients who require thoracic surgery. ${ }^{1}$ A weak capability to cough may lead to retention of pulmonary secretions and consequently life-threatening infectious complications, ${ }^{2}$ particularly during the postoperative course. Surgery remains the only radical treatment of endangering conditions, such as lung aspergilloma complicated by hemoptysis. ${ }^{3}$ Lung resection usually requires a predicted postoperative forced expiratory volume in 1 second $\left(\mathrm{FEV}_{1}\right)$ exceeding $30 \%$; otherwise, resection may be associated with a high postoperative mortality.

\section{CLINICAL SUMMARY}

A 35-year-old man was involved in a motor accident (12 years previously) causing T8 paraplegia complicated by phlebitis and pulmonary embolism. He underwent T3-L3 arthrodesis 7 years later to correct post-traumatic kyphoscoliosis that was complicated by C6 quadriplegia (with partial left arm mobility) and several bacterial pneumonias resulting in destruction of the right upper lobe, followed by aspergilloma formation and mild hemoptysis occurring several times per day. Treatment with an oral

From the Department of Thoracic Surgery, Georges Pompidou European Hospital, Paris-Descartes University, Paris, France.

Disclosures: Authors have nothing to disclose with regard to commercial support.

Received for publication March 22, 2012; revisions received July 5, 2012; accepted for publication Aug 1, 2012; available ahead of print Aug 23, 2012.

Address for reprints: Marc Riquet, PhD, MD, Department of Thoracic Surgery, Georges Pompidou European Hospital, 20 rue Leblanc 75015, Paris, France (E-mail: marc.riquet@egp.aphp.fr).

J Thorac Cardiovasc Surg 2012;144:e116-7

$0022-5223 / \$ 36.00$

Copyright (c) 2012 by The American Association for Thoracic Surgery

http://dx.doi.org/10.1016/j.jtcvs.2012.08.001 antifungic drug was stopped because of liver complication (cytolysis). Itraconazole proved to be ineffective. Aspergillous serology remained positive, and hemoptysis continued. Lobectomy was declined by 2 thoracic surgery centers because of the patient's low $\mathrm{FEV}_{1}: 570 \mathrm{~mL}$ (13\% of the predicted value).

The patient was referred to the Georges Pompidou European Hospital. He had no dyspnea, and room air saturation was $99 \%$ at rest. He was able to move himself using a wheelchair, but he had swallowing problems and an inability to cough. No abdominal muscle activity or accessory respiratory muscle contraction was observed. After 2 weeks in a pulmonary prehabilitation program, spirometry did not improve. $\mathrm{FEV}_{1}$ was still $13 \%$, vital capacity was $25 \%$ $(1350 \mathrm{~mL})$, and diffusing capacity of the lung for carbon monoxide was $37 \%$. Arterial oxygen tension was $100 \mathrm{~mm}$ $\mathrm{Hg}$, and arterial carbon dioxide tension was $45 \mathrm{~mm} \mathrm{Hg}$. However, except for an aspergilloma, the lung parenchyma was disease-free on the computed tomography scan, and lung perfusion was uniformly homogeneous in both lungs on ventilation-perfusion scan. We suspected that the real respiratory function was underestimated by spirometry and not interpretable in this patient. C6 quadriplegia explained the respiratory weakness with an $\mathrm{FEV}_{1}$ less than $20 \%$ of predicted. A right upper lobectomy was performed by video-assisted thoracoscopic surgery. A temporary prophylactic tracheostomy was performed to manage postoperative expectorating incapability problems and swallowing difficulties. The postoperative course was uneventful. The patient was weaned from mechanical ventilation within 24 hours, and the tracheostomy tube was removed on postoperative day 9. Intense chest physiotherapy continued 
postoperatively. The patient was symptom-free at the 5-year follow-up with unchanged $\mathrm{FEV}_{1}$.

\section{DISCUSSION}

This case illustrates that the interpretation of respiratory functional evaluation must not be considered independently of the patient context. At first, surgery was declined by overlooking the role of a neurologic deficit as the cause of the inability to perform expiratory maneuvers. We could not find other examples of lobectomy performed in quadriplegic patients with such a low preoperative $\mathrm{FEV}_{1}$. No functional data were available in the 3 lobectomies (performed by standard thoracotomy) reported by Rocco and colleagues, ${ }^{1}$ but the authors reported that preoperative evaluation may be limited, and the major emphasis must be on clinical expertise and arterial blood gas analysis to approximately determine the surgical risk. In the absence of diffuse pulmonary disease that explains major respiratory insufficiency, low preoperative $\mathrm{FEV}_{1}$ may not necessarily constitute a contraindication to surgery. In addition, vital capacity, which has been proposed as a single global measure of overall ventilatory function status in these cases, ${ }^{4}$ was not helpful. To avoid postoperative pulmonary infectious complications related to low expiratory flow rates and incapacity to expectorate, temporary tracheostomy might be a good adjunct to the surgical treatment. In a randomized controlled trial ${ }^{5}$ including 102 high-risk patients undergoing lung resection, a significantly lower rate of sputum retention was observed in the group with prophylactic tracheostomy compared with the control group, without early mortality linked to infectious lung complication.

\section{CONCLUSIONS}

The validity of pulmonary function tests in severe neurologic impairment should be considered with caution. These test results must not singly influence the decision-making for the anticipated operation when other criteria seem normal (rest of parenchyma, oxygen saturation). Prevention of complementary procedures, such as tracheostomy, might help to obtain better postoperative results.

\section{References}

1. Rocco G, Della Pona C, Massera F, Robustellini M, Rossi G, Rizz A, et al. Lobectomy for destroyed lung in quadriplegic patients. Ann Thorac Surg. 2000;69: 1002-5.

2. Jackson $\mathrm{AB}$, Groomes $\mathrm{TE}$. Incidence of respiratory complications following spinal cord injury. Arch Phys Med Rehabil. 1994;75:270-5.

3. Okubo K, Kobayashi M, Morikawa H, Hayatsu E, Ueno Y. Favorable acute and long-term outcomes after the resection of pulmonary aspergillomas. J Thorac Cardiovasc Surg. 2007;55:108-11.

4. Roth EJ, Nussbaum SB, Berkowitz M, Primack S, Oken J, Powly S, et al. Pulmonary function testing in spinal cord injury: correlation with vital capacity. Paraplegia. 1995;33:454-7.

5. Bonde P, Papachristos I, McCraith A, Kelly B, Wilson C, McGuigan JA, et al Sputum retention after lung operation: prospective randomized trial shows superiority of prophylactic minitracheostomy in hight-risk patients. Ann Thorac Surg. 2002;74:196-202.

\title{
Four-flap compound repair of thoracic hernia after sternum osteomyelitis and omentum flap
}

\author{
Christian Dirk Taeger, MD, Ulrich Kneser, MD, and Raymund E. Horch, MD, Erlangen, Germany
}

Sternal wound infections represent potentially lifethreatening complications in patients undergoing cardiovascular surgery. Although the incidence ranges from only $0.3 \%$ to $5 \%$, the condition is associated with

\footnotetext{
From the Department of Plastic and Hand Surgery, University Hospital Erlangen, Erlangen, Bavaria, Germany.

Director: Univ. Prof. Dr. med. Raymund E. Horch.

Disclosures: Authors have nothing to disclose with regard to commercial support.

Received for publication April 15, 2012; revisions received May 14, 2012; accepted for publication Aug 1, 2012; available ahead of print Aug 31, 2012.

Address for reprints: Christian Dirk Taeger, MD, Department of Plastic and Hand Surgery, University Hospital Erlangen, Krankenhausstrasse 12, Erlangen, Bavaria 91054, Germany (E-mail: christian.taeger@uk-erlangen.de)

J Thorac Cardiovasc Surg 2012;144:e117-9

$0022-5223 / \$ 36.00$

Copyright (C) 2012 by The American Association for Thoracic Surgery

http://dx.doi.org/10.1016/j.jtcvs.2012.08.004
}

significant mortality of $14 \%$ to $47 \%$ in the published data. $^{1}$

Different approaches have been tried to manage poststernotomy osteomyelitis, including surgical revision followed by open dressings or closed irrigation and reconstruction with vascularized soft tissue flaps. The omentum flap represents an alternative technique that was primarily used in the past. ${ }^{2}$ Its use was hampered by the additional surgical trauma, turning a "1-cavity" into a "2-cavity" surgery, with a much wider range of possible complications, such as pain, reduced thoracic compliance, and a significant risk of hiatal and midline hernia formation. 1

The standard techniques of sternal wound coverage such as the pectoralis major flap have limited applicability in defects in the lower third of the sternum, and a cranially 